\title{
PENGARUH MOTIVASI KERJA DAN KOMPENSASI TERHADAP KINERJA PEGAWAI
}

\author{
Egi Saputro ${ }^{1}$, Ahmad Darda ${ }^{2}$ \\ ${ }^{1}$ STIE Muhammadiyah Jakarta, egi.kramat16@yahoo.com \\ ${ }^{2}$ STIE Muhammadiyah Jakarta, ahmaddarda556@yahoo.co.id
}

\begin{abstract}
ABSTRAK
Kurangnya motivasi kerja pegawai honorer, serta masih kurangnya tingkat pemberian kompensasi terhadap pegawai honorer menjadi dasar dalam melakukan penelitian ini yang mana bertujuan untuk mengetahui apakah motivasi kerja dan kompensasi berpengaruh terhadap kinerja pegawai honorer pada Rumah Sakit Penyakit Infeksi Prof. Dr. Sulianti Saroso Jakarta. Teknik penentuan sampel dalam penelitian ini menggunakan teknik non probability sampling yaitu tidak semua anggota populasi dapat dipilih menjadi sampel jumlah sampel diambil yaitu menggunakan rumus slovin dan mendapatkan sampel sebanyak 60 responden. Analisis data menggunakan regresi berganda. Hasil prngujian motivasi kerja dan kompensasi memiliki pengaruh posistif dan signifikan terhadap kinerja pegawai honorer pada Rumah Sakit Penyakit Infeksi Prof. Dr. Sulianti Saroso Jakarta. Semakin baik motivasi kerja dan semakin tinggi kompensasi yang diberikan akan meningkatkan kinerja pegawai.
\end{abstract}

Kata Kunci: Motivasi Kerja, Kompensasi, Kinerja

\begin{abstract}
The main problem to be examined in this study is that there is still a lack of work motivation of honorary employees, as well as a lack of levels of compensation for temporary employees. So this study aims to determine whether work motivation and compensation affect the performance of honorary employees at the Infection Hospital Prof. Dr. Sulianti Saroso Jakarta. The sampling technique in this study uses non-probability sampling technique that is not all members of the population can be selected as samples. This technique is carried out because there is a large population of more than 100 respondents, so the number of samples is taken using Slovin formula and getting a population of 60. Analysis of the data used is multiple regression analalysis. The results of testing work motivation and compensation have a positive and significant influence on the performance of honorary employees at the Infection Hospital Prof. Dr. Sulianti Saroso Jakarta.
\end{abstract}

Keywords: Work Motivation, Compensation, Performance

\section{PENDAHULUAN}

Sumber daya manusia berkualitas tinggi adalah sumber daya manusia yang mampu menciptakan bukan saja nilai komparatif tetapi juga nilai kompetitif, generatif, inovatif dengan menggunakan energi tertinggi seperti intelligence, creativity dan imagination. Setiap perusahaan akan selalu berusaha untuk meningkatkan kinerja pegawainya, dengan harapan apa yang menjadi tujuan perusahaan akan tercapai. Menurut Gunawan (2018) Sumber daya manusia yang berkualitas, bermotivasi tinggi dan mau bekerja sama dalam team akan menjadi kunci keberhasialan organisasi. Karena itu pimpinan harus dapat menetapkan sasaran kerja yang akan menghasilkan pegawai yang berkualitas tinggi, bermotivasi tinggi dan produktif. Penetapan target-target spesifik dalam kurun waktu tertentu tidak hanya bersifat kuantitatif tetapi juga bersifat kualitatif misalnya, dengan pengembangan diri untuk menguasai pengetahuan dan keahlian yang diperlukan untuk pekerjaan dengan tingkat kompetensi yang makin baik. 
Begitu pula yang dilakukan oleh Rumah Sakit Infeksi Prof. Dr. Sulianti Saroso Jakarta yang selalu berusaha membuat karyawan baik itu karyawan tetap maupun karyawan honorer untuk mendapatkan perhatian dalam segi kesejahteraan karyawan demi meningkatkan kinerjanya, akan tetapi melalui pengamatan yang dilakukan pada Rumah Sakit Penyakit Infeksi Prof. Dr. Sulianti Saroso Jakarta ditemukan kecenderungan penurunan kinerja pegawai honorer, hal ini ditandai dengan terdapat beberapa pegawai honorer yang tidak menyelesaikan pekerjaan tepat waktu sehingga menyebabkan banyak pekerjaan yang terbengakalai. Berdasarkan hasil pengamatan disimpulkan bahwa faktor yang mempengaruhi kinerja karyawan honorer Rumah Sakit Infeksi Prof. Dr. Sulianti Saroso Jakarta adalah motivasi dan kompensasi. Pengungkapan motivasi dan kompensasi sebagai faktor yang mempengaruhi kinerja juga dikemukakan oleh Sahidaria (2015) yang menyatakan bahwa Kompensasi dan Motivasi Kerja berpengaruh positif terhadap Kinerja Karyawan, begitu pula dengan penelitan yang dilakukan Prakoso (2016) yang menyatakan bahwa motivasi dan kompensasi juga berpengaruh positif terhadap kinerja karyawan, akan tetapi penelitian yang dilakukan oleh Aromega et.al (2019) menyatakan bahwa kompensasi berpengaruh negatif terhadap kinerja karyawan. Sehingga terdapat gap dari hasil penelitian yang telah dilakukan, oleh karena itu diperlukan suatu kajian yang komprehensif mengenai faktor-faktor yang berpengaruh terhadap kinerja karyawan. Dan tujuan dari penelitian ini adalah untuk mengungkapkan apakah faktor motivasi dan kompensasi juga berpengaruh terhadap kinerja pegawai honorer Rumah Sakit Penyakit Infeksi Prof. Dr. Sulianti Saroso Jakarta. Berdasarkan paparan di atas, penelitian ini bertujuan untuk mengetahui adanya permasalahan tersebut diduga adanya pengaruh motivasi kerja dan kompensasi terhadap kinerja pegawai honorer pada rumah sakit penyakit infeksi prof. dr. sulianti saroso Jakarta.

\section{KAJIAN LITERATUR \\ Motivasi}

Menurut Hasibuan (2011:141) Motivasi berasal dari kata Latin (movere) yang berarti dorongan atau menggerakkan. Motivasi dalam manajemen hanya ditujukan pada sumber daya manusia pada umumnya dan bawahan khususnya. Menurut Winardi (2011:6), Motivasi adalah suatu kekuatan potensial yang ada di dalam diri seorang manusia, yang dapat dikembangkannya sendiri atau dikembangkan oleh sejumlah kekuatan luar yang pada intinya berkisar sekitar imbalan moneter dan imbalan non moneter, yang dapat mempengaruhi hasil kinerjanya secara positif atau negatif, hal mana tergantung pada situasi dan kondisi yang dihadapi orang yang bersangkutan.

\section{Kompensasi}

Menurut Veithzal Rivai (2011:357), menjelaskan bahwa kompensasi merupakan sesuatu yang karyawan dapatkan sebagai pengganti kontribusi jasa mereka pada perusahaan. Sedangkan, menurut Sutrisno (2012:182), mengemukakan bahwa kompensasi adalah dihitung berdasarkan evaluasi pekerjaan, perhitungan kompensasi berdasarkan evaluasi pekerjaan dimaksudkan untuk mendapatkan pemeberian kompensasi yang mendekati kelayakan (worth) dan keadilan(equity). Menurut Sutrisno (2012:182), kompensasi adalah semua balas jasa yang diterima seseorang karyawan dari perusahaannya sebagai akibat dari jasa/tenaga yang telah diberikannya pada perusahaan tersebut.

\section{Kinerja}

Menurut Sedarmayanti (2011:260) mengungkapkan bahwa kinerja merupakan terjemahan dari performance yang berarti Hasil kerja seorang pekerja, sebuah proses manajemen atau suatu organisasi secara keseluruhan, dimana hasil kerja tersebut harus dapat ditunjukkan buktinya secara konkrit dan dapat diukur (dibandingkan dengan standar yang telah ditentukan). 


\section{Pengembangan Hipotesis}

Penelitian yang dilakukan Hasbullah dan Rumansyah (2011) menyatakan bahwa terdapat pengaruh positif antara motivasi dengan kinerja karyawan. Kasmir (2016, p.190) menyatakan jika karyawan memiliki dorongan yang kuat dari dalam dirinya atau dorongan dari luar dirinya (misalnya dari pihak perusahaan), maka karyawan akan terdorong untuk melakukan sesuatu dengan baik. Pada akhirnya dorongan atau rangsangan baik dari dalam maupun dari luar diri seseorang ini akan menghasilkan kinerja yang baik, demikian pula sebaliknya. Berdasarkan teori dan penelitian terdahulu maka dibuat hipotesis penelitian pertama yaitu:

H1: Motivasi Kerja berpengaruh terhadap kinerja pegawai honorer Pada Rumah sakit Penyakit Infeksi Prof. Dr. Sulianti Saroso Jakarta.

Catherine Nathania (2016) dalam penelitiannya yang berjudul Pengaruh Kompensasi Terhadap Kinerja Karyawan Pada PD Damai Motor Bandar Lampung. Berdasarkan penelitiannya adalah variable bebas yaitu kompensasi berpengaruh yang signifikan terhadap variable terikat yaitu kinerja karyawan. Muhimatur Rofi"eah (2012) telah mengadakan suatu penelitian tentang Pengaruh Kompensasi Terhadap Kinerja Pegawai (studi kasus pada PT.Bank Tabungan Negara (Persero) Tbk Kantor Cabang Syariah Malang. Berdasarkan penelitiannya adalah variable bebas yaitu kompensasi berpengaruh yang signifikan terhadap variable terikat yaitu kinerja karyawan.

Berdasarkan teori dan penelitian terdahulu maka dibuat hipotesis penelitian kedua yaitu:

H2: Kompensasi berpengaruh terhadap kinerja pegawai honorer Pada Rumah sakit Penyakit Infeksi Prof. Dr. Sulianti Saroso Jakarta.

Sahidaria (2015) meneliti tentang Pengaruh Kompensasi dan Motivasi Kerja Terhadap Kinerja Karyawan Pada PT. Buri Sonikijaya Padang. Berdasarkan penelitiannya adalah terdapat pengaruh yang signifikan antara kompensasi terhadap kinerja karyawan begitu pula dengan motivasi kerja berpengaruh yang signifikan terhadap kinerja karyawan. Medi Prakoso (2016) dengan judul penelitian Pengaruh Motivasi Kerja dan Kompensasi Terhadap Kinerja Karyawan percetakan Art Studio Jakarta Pusat. Berdasarkan penelitiannya adalah motivasi kerja berpengaruh positif terhadap kinerja karyawan, kompensasi berpengaruh positif terhadap kinerja karyawan, motivasi kerja dan kompensasi berpengaruh positif terhadap kinerja karyawan.

Berdasarkan teori dan penelitian terdahulu maka dibuat hipotesis penelitian kedua yaitu:

H3: Motivasi Kerja dan Kompensasi berpengaruh secara simultan terhadap kinerja pegawai honorer Pada Rumah sakit Penyakit Infeksi Prof. Dr. Sulianti Saroso Jakarta.

Berdasarkan keterkaitan teori antar variable dan peneliti sebelumnya maka dibuat kerangka pikir sebagai berikut:

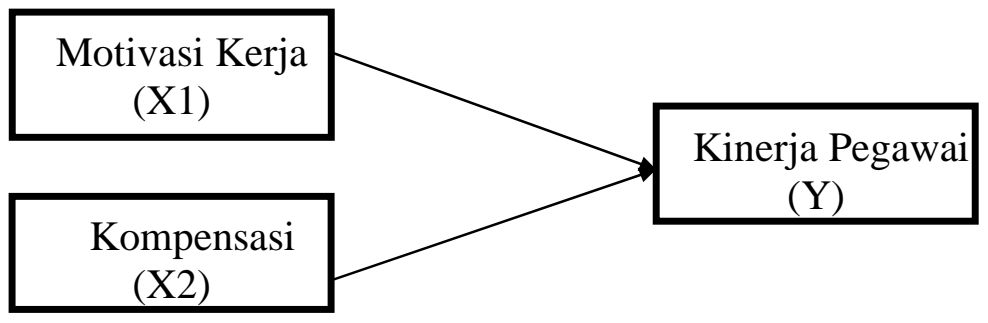

Gambar 1. Kerangka Pemikiran 


\section{METODE PENELITIAN}

Responden yang dijadikan dalam penelitian ini adalah pegawai honorer Rumah Sakit Penyakit Infeksi Prof. Dr. Sulianti Saroso Jakarta dengan jumlah sample sebanyak 60 responden. Berikut ini adalah variabel, indikator yang digunakan dalam penelitian ini :

Tabel 1. Operasional Variabel Penelitian

\begin{tabular}{|c|c|c|c|c|}
\hline No & Variabel & Indikator & $\begin{array}{c}\text { Skala } \\
\text { Pengukuran }\end{array}$ & Instrumen \\
\hline 1 & $\begin{array}{c}\text { Motivasi Kerja }\left(X_{1}\right) \\
\text { (Mangkunegara, } \\
\text { 2013:89) }\end{array}$ & $\begin{array}{l}\text { 1. Usaha Untuk Maju } \\
\text { 2. Pemanfaatan Waktu } \\
\text { 3. Ketekunan } \\
\text { 4. Kerja Keras } \\
\begin{array}{l}\text { 5. Orientasi Masa } \\
\text { Depan }\end{array}\end{array}$ & Skala Likert & Kuesioner \\
\hline 2 & $\begin{array}{l}\text { Kompensasi }\left(X_{2}\right) \\
\text { (Veithzal Rivai } \\
(2011: 357)\end{array}$ & $\begin{array}{l}\text { 1. Gaji } \\
\text { 2. Bonus } \\
\text { 3. Insentif } \\
\text { 4. Fasilitas } \\
\text { 5. Asuransi } \\
\text { 6. Tunjangan }\end{array}$ & Skala Likert & Kuesioner \\
\hline 3 & $\begin{array}{l}\text { Kinerja (Y) } \\
\text { (Mangkunegara } \\
\text { 2013:75) }\end{array}$ & $\begin{array}{l}\text { 1. Kualitas kerja } \\
\text { 2. Kuantitas Kerja } \\
\text { 3. Keandalan } \\
\text { 4. Sikap Kerja }\end{array}$ & Skala Likert & Kuesioner \\
\hline
\end{tabular}

Pengujian hipotesis dilakukan dengan membandingkan nilai signifikansi pada output SPSS, jika signifikansi < 0,05 maka hipotesis diterima dan sebaliknya (Wati, 2017).

\section{HASIL PENELITIAN}

\section{Karakteristik Responden}

Responden yang paling banyak berpartisipasi pada penelitian ini berjenis kelamin laki laki yaitu sebanyak 39 orang (65\%) dan yang berjenis kelamin perempuan sebanyak 21 orang (35\%). Yang mana usia antara 20 - 25 sebanyak 24 orang (40\%), responden pada usia antara 26 - 30 sebanyak 17 orang (28\%), responden pada usia antara 31 - 35 sebanyak 13 orang (22\%), dan juga responden yang berusia diatas 35 tahun sebanyak 6 orang (10\%). Kemudian responden pada masa kerja antara $1-5$ tahun sebanyak 42 orang (70\%), sedangkan responden pada masa kerja antara $6-10$ tahun sebanyak 18 orang (30\%), dengan pendidikan SMA/SMK sebanyak 38 orang $(63 \%)$, responden dengan pendidikan D3 sebanyak 12 orang (20\%), sedangkan responden dengan pendidikan S1 sebanyak 10 orang (17\%).

\section{Analisis Data \\ Uji Validitas}

Uji validitas digunakan untuk melihat sejauh mana ketepatan dan kecermatan suatu alat ukur melaksanakan fungsi ukurnya. Uji validitas digunakan dengan menggunakan metode 
Product Moment Pearson. Bila dari hasil pengujian lebih besar dari 0,30 $(r \geq 0,30)$ instrumen dikatakan valid. Pengujian dilakukan dengan menggunakan program SPSS Statistics.

Tabel 2. Hasil Uji Validitas Variabel Motivasi Kerja

\begin{tabular}{|c|c|c|}
\hline Pernyataan 1 & 0,642 & Valid \\
\hline Pernyataan 2 & 0,656 & Valid \\
\hline Pernyataan 3 & 0,603 & Valid \\
\hline Pernyataan 4 & 0,554 & Valid \\
\hline Pernyataan 5 & 0,477 & Valid \\
\hline Pernyataan 6 & 0,677 & Valid \\
\hline Pernyataan 7 & 0,561 & Valid \\
\hline Pernyataan 8 & 0,712 & Valid \\
\hline Pernyataan 9 & 0,602 & Valid \\
\hline Pernyataan 10 & 0,568 & Valid \\
\hline
\end{tabular}

Sumber : Hasil Olah Data Program SPSS

Berdasarkan tabel diatas dari hasil uji valliditas variabel motivasi kerja menunjukan hasil yang valid karena nilai korelasi pearson diatas 0,30. Maka dapat disimpulkan seluruh item pertanyaan dapat digunakan sebagai alat ukur untuk variabel motivasi kerja.

Tabel 3. Hasil Uji Validitas Variabel Kompensasi

\begin{tabular}{|c|c|c|}
\hline Pernyataan 1 & 0,624 & Valid \\
\hline Pernyataan 2 & 0,633 & Valid \\
\hline Pernyataan 3 & 0,588 & Valid \\
\hline Pernyataan 4 & 0,564 & Valid \\
\hline Pernyataan 5 & 0,363 & Valid \\
\hline Pernyataan 6 & 0,569 & Valid \\
\hline Pernyataan 7 & 0,625 & Valid \\
\hline Pernyataan 8 & 0,354 & Valid \\
\hline Pernyataan 9 & 0,467 & Valid \\
\hline Pernyataan 10 & 0,559 & Valid \\
\hline
\end{tabular}

Sumber : Hasil Olah Data Program SPSS

Berdasarkan tabel diatas dari hasil uji valliditas variabel motivasi kerja menunjukan hasil yang valid karena nilai korelasi pearson diatas 0,30. Maka dapat disimpulkan seluruh item pertanyaan dapat digunakan sebagai alat ukur untuk variabel kompensasi.

Tabel 4. Hasil Uji Validitas Variabel Kinerja Pegawai

\begin{tabular}{|c|c|c|}
\hline Pernyataan 1 & 0,610 & Valid \\
\hline Pernyataan 2 & 0,642 & Valid \\
\hline Pernyataan 3 & 0,558 & Valid \\
\hline Pernyataan 4 & 0,662 & Valid \\
\hline Pernyataan 5 & 0,545 & Valid \\
\hline Pernyataan 6 & 0,501 & Valid \\
\hline Pernyataan 7 & 0,680 & Valid \\
\hline Pernyataan 8 & 0,417 & Valid \\
\hline
\end{tabular}




\begin{tabular}{|c|c|c|}
\hline Pernyataan 9 & 0,584 & Valid \\
\hline Pernyataan 10 & 0,319 & Valid \\
\hline
\end{tabular}

\section{Sumber : Hasil Olah Data Program SPSS}

Berdasarkan tabel diatas dari hasil uji valliditas variabel motivasi kerja menunjukan hasil yang valid karena nilai korelasi pearson diatas 0,30. Maka dapat disimpulkan seluruh item pertanyaan dapat digunakan sebagai alat ukur untuk variabel kinerja karyawan.

\section{Uji Realibilitas}

Tujuan pengujian reliabilitas adalah untuk melihat apakah instrument penelitian merupakan instrument yang handal dan dapat dipercaya. Menurut Wati (2017) menyatakan bahwa jika nilai koefisien reliabilitas lebih besar > 0,6 maka instrumen memilikin reliabilitas yang baik, relibel, atau terpercaya.

Tabel 5. Hasil Uji Reliabilitas

\begin{tabular}{|l|c|c|}
\hline \multicolumn{1}{|c|}{ Variabel } & $\begin{array}{c}\text { Jumlah } \\
\text { Pernyataan }\end{array}$ & $\begin{array}{c}\text { Cronbach } \\
\text { Alpha }\end{array}$ \\
\hline Motivasi Kerja & 10 Item & 0,806 \\
\hline Kompensasi & 10 Item & 0,720 \\
\hline Kinerja Pegawai & 10 Item & 0,717 \\
\hline \multicolumn{2}{|c|}{ Sumber: Hasil Olah Data Program SPSS }
\end{tabular}

Berdasarkan hasil dari uji reliabilitas diatas pada variabel motivasi kerja, kompensasi dan kinerja pegawai, uji reliabilitas diatas pada seluruh variabel menunjukkan nilai cronbach's alpha berada di atas 0.60 . dari hasil tersebut maka alat ukur yang digunakan dalam penelitian ini telah memenuhi syarat dan dapat diandalkan.

\section{PENGUJIAN HIPOTESIS}

Hasil Uji Parsial (Uji F)

Uji T dilakukan untuk menguji secara parsial apakah motivasi kerja $\left(\mathrm{X}_{1}\right)$ dan kompensasi $\left(\mathrm{X}_{2}\right)$ secara parsial atau masing - masing berpengaruh signifikan terhadap kinerja pegawai honorer (Y) pada Rumah Sakit Penyakit Infeksi Prof. Dr. Sulianti Saroso Jakarta. Sebagai berikut:

Tabel 6. Hasil Uji T (Uji Parsial)

\section{Coefficients $^{\mathrm{a}}$}

\begin{tabular}{|c|c|c|c|c|c|}
\hline \multirow[t]{2}{*}{ Model } & \multicolumn{2}{|c|}{$\begin{array}{l}\text { Unstandardized } \\
\text { Coefficients }\end{array}$} & \multirow{2}{*}{$\begin{array}{l}\text { Standardize } \\
\text { d } \\
\text { Coefficients } \\
\text { Beta }\end{array}$} & \multirow[b]{2}{*}{$\mathrm{t}$} & \multirow[b]{2}{*}{ Sig. } \\
\hline & $B$ & Std. Error & & & \\
\hline $1 \quad$ (Constant) & 11,113 & 3,337 & & 3,331 & ,002 \\
\hline Motivasi (X1) & ,316 & ,083 & ,382 & 3,798 & ,000 \\
\hline $\begin{array}{c}\text { Kompensasi } \\
\text { (X2) }\end{array}$ & ,405 & ,087 & ,471 & 4,683 & ,000 \\
\hline
\end{tabular}

Sumber : Hasil Olah Data Program SPSS 
Berdasarkan pengujian uji t menggunakan SPSS pada tabel 4.13, untuk variabel Motivasi Kerja nilai t hitung sebesar 3,798 yang hasilnya lebih besar dari t tabel yaitu 2,002 dengan signifikansi sebesar 0,000. Untuk variabel kompensasi t hitung sebesar 4,683 yang hasilnya lebih besar dari t tabel yaitu 2,002 dengan signifikansi sebesar 0,000. Dari data diatas dapat dinyatakan bahwa $\mathrm{HO}$ ditolak dan $\mathrm{H} 1$ diterima, yang artinya bahwa terdapat pengaruh yang positif dan signifikan secara parsial antara motivasi kerja dan kompensasi terhadap kinerja pegawai honorer di Rumah Sakit Penyakit Infeksi Prof. Dr. Sulianti Saroso Jakarta.

\section{Hasil Uji Simultan (Uji T)}

Pengujian ini dilakukan untuk melihat secara bersama-sama pengaruh atau hubungan positif dan signifikan variabel bebas $\left(\mathrm{X}_{1}\right.$, dan $\left.\mathrm{X}_{2}\right)$ berupa Motivasi Kerja dan kompensai terhadap variabel terikat (Y) kinerja pegawai honorer pada Rumah Sakit Penyakit Infeksi Prof. Dr. Sulianti Saroso Jakarta. Untuk pengujian Uji F menggunakan program SPSS adalah sebagai berikut :

Tabel 7. Hasil Uji Simultan (Uji F)

ANOVA $^{\text {b }}$

\begin{tabular}{|c|c|c|c|c|c|}
\hline Model & $\begin{array}{l}\text { Sum of } \\
\text { Squares }\end{array}$ & $d f$ & Mean Square & $\mathrm{F}$ & Sig. \\
\hline 1 Regression & 568,405 & 2 & 284,202 & 25,805 &, $000^{a}$ \\
\hline Residual & 627,779 & 57 & 11,014 & & \\
\hline Total & 1196,183 & 59 & & & \\
\hline
\end{tabular}

a. Predictors: (Constant), Kompensasi (X2), Motivasi (X1)

b. Dependent Variable: Kinerja $(Y)$

Sumber : Hasil Olah Data Program SPSS

Berdasarkan tabel 4.14 dapat dilihat hasil Uji $\mathrm{F}$ secara simultan, dapat diperoleh nilai $\mathrm{F}$ hitung 25,805 dengan tingkat signifikansi 0,000. Sedangkan nilai $F$ tabel 3,18. Nilai $F$ hitung $>F$ tabel $(25,805>3,18)$ dan tingkat signifikansi $(0.000<0,05)$ dengan hipotesis $\mathrm{H}_{0}$ ditolak dan $\mathrm{H}_{\mathrm{a}}$ diterima sehingga dapat disimpulkan bahwa variabel bebas yaitu Motivasi Kerja $\left(\mathrm{X}_{1}\right)$, dan kompensasi $\left(\mathrm{X}_{2}\right)$ secara bersama-sama berpengaruh positif dan signifikan terhadap variabel kinerja pegawai honorer pada Rumah Sakit Penyakit Infeksi Prof. Dr. Sulianti Saroso Jakarta.

\section{Hasil Uji Koefisien Determinasi $\left(\mathbf{R}^{2}\right)$}

Pengujian Koefisien determinasi adalah untuk mengetahui jumlah besaran persentase dan digunakan untuk mengukur seberapa besar kontribusi variabel bebas motivasi kerja dan kompensasi terhadap variabel terikat kinerja pegawai honorer pada Rumah Sakit Penyakit Infeksi Prof. Dr. Sulianti Saroso Jakarta.

Tabel 7. Hasil Uji Koefisien Determinasi Model Summary

\begin{tabular}{|c|c|c|c|c|}
\hline Model & $\mathrm{R}$ & $\mathrm{R}$ Square & $\begin{array}{c}\text { Adjusted } \mathrm{R} \\
\text { Square }\end{array}$ & $\begin{array}{c}\text { Std. Error of the } \\
\text { Estimate }\end{array}$ \\
\hline 1 &, $689^{\mathrm{a}}$ &, 475 &, 457 & 3,31868 \\
\hline
\end{tabular}

a. Predictors: (Constant), Kompensasi (X2), Motivasi (X1)

Sumber : Hasil Olah Data Program SPSS 
Berdasarkan dari hasil tabel output model summary diatas, nilai dari koefisien R sebesar 0,689 yang artinya variabel motivasi kerja dan kompensasi memiliki hubungan terhadap kinerja pegawai honorer pada Rumah Sakit Penyakit Infeksi Prof. Dr. Sulianti Saroso Jakarta, untuk hasil $\mathrm{R}^{2}$ square sebesar 0,475 atau $47,5 \%$. Artinya variabel motivasi kerja dan kompensasi dapat menjelaskan perngaruh terhadap kinerja pegawai honorer dengan hasil kontribusi sebesar $47,5 \%$. Sedangkan sisanya untuk 52,5\% dijelaskan untuk variabel lain yang tidak diteliti dan dijelaskan dalam penelitian ini.

\section{PEMBAHASAN \\ Pengaruh Motivasi Terhadap Kinerja}

Berdasarkan pengujian uji parsial (uji t) hipotesis X1 diperoleh bahwa motivasi memiliki pengaruh positif dan signifikan terhadap kinerja pegawai. Pengujian pengaruh variabel motivasi terhadap kinerja pegawai dapat diketahui dengan melihat nilai t hitung sebesar 3,798 dan $t$ tabel sebesar 2,002 dengan signifikansi sebesar 0,000. Dengan nilai t hitung lebih besar dari $\mathrm{t}$ tabel dan nilai signifikansi yang berada di bawah 0,05 yang menunjukkan adanya pengaruh yang signifikan dari variabel motivasi terhadap kinerja pegawai. Hasil pengujian hipotesis menunjukan bahwa motivasi kerja secara parsial berpengaruh positif dan signifikan terhadap kinerja pegawai.

Hasil penelitian ini mendukung peneliti sebelumnya Kori Pratiwi (2010) yaitu terdapat pengaruh yang kuat antara motivasi terhadap kinerja karyawan. Terdapat hubungan positif antara motivasi dengan kinerja karyawan PT. Bank Muamalat Indonesia Cabang Palembang. Artinya dari kedua penelitian yang telah dilakukan motivasi sama-sama berpengaruh positif terhadap kinerja pegawai.

\section{Pengaruh Kompensasi Terhadap Kinerja}

Berdasarkan pengujian uji parsial (uji t) hipotesis X2 diperoleh bahwa kompensasi memiliki pengaruh positif dan signifikan terhadap kinerja pegawai. Pengujian pengaruh variabel kompensasi terhadap kinerja pegawai dapat diketahui dengan melihat nilai $\mathrm{t}$ hitung sebesar 4,683 dan t tabel sebesar 2,002 dengan signifikansi sebesar 0,000. Dengan nilai t hitung lebih besar dari t tabel dan nilai signifikansi yang berada di bawah 0,05 yang menunjukkan adanya pengaruh yang signifikan dari variabel kompensasi terhadap kinerja pegawai. Sehingga hipotesis kedua yang menyatakan bahwa kompensasi memiliki pengaruh terhadap kinerja karyawan diterima. Hasil pengujian hipotesis menunjukan bahwa kompensasi secara parsial dapat secara parsial berpengaruh positif dan signifikan terhadap kinerja.

Hasil dari penelitian sebelumnya Catherine Nathania (2016) dalam penelitiannya yang berjudul pengaruh kompensasi terhadap kinerja karyawan pada PD Damai Motor Bandar Lampung. Berdasarkan penelitiannya adalah variable bebas yaitu kompensasi berpengaruh yang signifikan terhadap variable terikat yaitu kinerja karyawan. Artinya dari kedua penelitian yang telah dilakukan kompensasi sama-sama berpengaruh positif terhadap kinerja pegawai.

\section{Pengaruh motivasi dan kompensasi terhadap kinerja}

Berdasarkan hasil uji $\mathrm{F}$ (simultan) menunjukkan nilai $\mathrm{F}$ hitung sebesar 25,805 nilai ini lebih besar dari nilai $\mathrm{F}$ tabel 3,18 dengan tingkat signifikansi 0,000. Karena nilai signifikansi jauh lebih kecil dari 0,05 maka motivasi kerja dan kompensasi secara bersama-sama berpengaruh terhadap kinerja pegawai. Hasil pengujian hipotesis menunjukan bahwa motivasi kerja dan kompensasi secara simultan berpengaruh positif dan signifikan terhadap kinerja pegawai. Berdasarkan hasil penelitian menunjukkan bahwa nilai variabel motivasi 3,798, sedangkan kompensasi 4,683.

Hasil penelitian ini mendukung peneliti sebelumnya Medi Prakoso (2016) yang menyatakan bahwa motivasi kerja berpengaruh positif terhadap kinerja karyawan, kompensasi berpengaruh positif terhadap kinerja karyawan, motivasi kerja dan kompensasi berpengaruh 
positif terhadap kinerja karyawan. Artinya dari kedua penelitian yang telah dilakukan motivasi kompensasi sama-sama berpengaruh positif dan signifikan terhadap kinerja pegawai.

\section{PENUTUP}

Secara empiris, dari hasil pengujian diperoleh bahwa motivasi memiliki pengaruh positif dan signifikan terhadap kinerja pegawai. Hal tersebut berarti bahwa semakin tinggi motivasi kerja seorang pegawai maka akan semakin baik kinerja pegawai tersebut. Hasil pengujian pengaruh Kompensasi terhadap kinerja kinerja karyawan berpengaruh positif dan signifikan. Hal tersebut berarti bahwa semakin baik pemberian kompensasi yang diberikan pegawai maka akan semakin baik kinerja pegawai tersebut. Motivasi dan kompensasi secara simultan memiliki pengaruh positif signifikan terhadap variabel dependen yaitu kinerja perusahaan. Hal tersebut berarti bahwa semakin tinggi motivasi kerja dan pemberian kompensasi yang adil maka kinerja pegawai honorer yang ada di Rumah Sakit Penyakit Infeksi Prof. Dr. Sulianti Saroso Jakarta akan meningkat.

Adapun saran dari hasil penelitian ini, perusahaan harus meningkatkan motivasi kerja dan pemberian kompensasi yang baik agar kinerja karyawan meningkat signifikan. Ketika kinerja karyawan meningkat maka berdampak langsung terhadap peningkatan kinerja Rumah Sakit Penyakit Infeksi Prof. Dr. Sulianti Saroso Jakarta. Keterbatasan penelitian ini hanya menguji dua factor penentu kinerja pegawai yaitu motivasi kerja dan kompensasi, masih banyak variable lain di luar model penelitian yang menjadi factor penentu kinerja pegawai. Untuk itu diharapkan peneliti yang akan datang menambahkan jumlah variable independent.

\section{REFERENSI}

Aromega, Tanod Nanda, (2019) Articles Pengaruh Kompensasi Dan Disiplin Kerja Terhadap Kinerja Karyawan Di Yuta Hotel Manado. Universitas Sam Ratulangi, Indonesia

Gunawan, Andri. (2018). Pengaruh Pendidikan, Pelatihan dan Kedisiplinan terhadap Kinerja Pegawai pada Kantor KPP Setiabudi Jakarta Selatan. Jurnal Ekobis: Ekonomi Bisnis \& Manajemen Volume 8 Nomor 1. Sekolah Tinggi Ilmu Ekonomi Muhammadiyah Jakarta.

Hasbullah, R., \& Rumansyah, H. B. (2011). Pengaruh Motivasi Terhadap Kinerja Karyawan di Outlet PT . Sinarmas Multifinance Cabang Telagasari Karawang, 9(1), 548-559.

Hasibuan, Malayu S.P., (2011). Manajemen Sumber Daya Manusia. Bumi Aksara, Jakarta

Kasmir. (2016). Manajemen Sumber Daya Manusia (Teori dan Praktik) (1st ed.). Jakarta: PT RajaGrafindo Persada

Nathania, Catherine. (2016) Pengaruh Kompensasi Terhadap Kinerja Karyawan Pada PD Damai Motor Bandar Lampung (Skripsi). Fakultas Ekonomi Dan Bisnis Universitas Lampung Bandar Lampung

Prakoso, Medi. (2016). Pengaruh Motivasi Kerja dan Kompensasi terhadap Kinerja Karyawan Percetakan Art Studio. Skripsi. Jakarta Pusat: Universitas Bung Karno.

Rivai, Veithzal. (2011), Manajemen Sumber Daya Manusia untuk Perusahaan: dari Teori ke Praktik, Jakarta : RajaGrafindo Persada

Rofi'ah, Muhimatur, (2012). Pengaruh Kompensasi Terhadap Kinerja Pegawai (Studi Kasus Pada PT. Bank Tabungan Negara (Persero),Tbk. Kantor Cabang Syariah Malang). Skripsi Program Sarjana, Jurusan Manajemen, Universitas Islam Negeri Maulana Malik Ibrahim Malang.

Sahidaria (2015) Pengaruh Kompensasi dan Motivasi Kerja Terhadap Kinerja Karyawan pada PT.Buri Sonikjaya Padang, Jurnal Universitas Taman Siswa Padang

Sahidaria (2015) Pengaruh Kompensasi dan Motivasi Kerja Terhadap Kinerja Karyawan pada PT.Buri

Sedarmayanti. (2011). Manajemen Sumber Daya Manusia, Reformasi Biroksi dan Manajemen Pegawai Negeri Sipil (cetakan kelima). Bandung : PT Refika Aditama 
Sutrisno, Edy. (2012). Manajemen Sumber Daya Manusia. Edisi 1. Cetakan Keempat. Prenada Media Group. Jakarta.

Wati, L.N. (2017). Metodologi Penelitian Bisnis Terapan, Aplikasi SPSS, EVIEWS, Smart PLS, dan AMOS. Percetakan Mujahid: Bandung

Winardi. (2011). Motivasi Pemotivasian dalam Manajemen. Jakarta: Grafindo Persada. 